LEVITAN, M. I95I $c$. Response of the chormosomal variability in $D$. robusta to seasonal factors in a South-west Virginia Wood (Abstr.) Records. Genet. Soc. Amer., 20, 109-I Io.

mather, W. B. I96r. Chromosomal polymorphism in Drosophila rubida Mather. Genetics, 46, 797-810.

mather, w. B. Ig63a. Patterns of chromosomal polymorphism in Drosophila rubida. Am. Naturalist, 97, 59-64.

MATHER, W. B. I963 $b$. Ecological and sexual variation in Drosophila rubida inversion polymorphism. Heredity, I8, Iog-I I I.

STRICKBERger, M. W. I962. Experiments in genetics with Drosophila. John Wiley. TOWNSEND, S. I. 1952. Genetics of marginal populations of Drosophila willistoni. Evolution, 6, 428-442.

\title{
CANALISATION AND THRESHOLD EFFECT OF THE EXTRA SCUTELLAR PHENOTYPE IN DROSOPHILA MELANOGASTER
}

\author{
RAM PARSHAD and RAVI DUTT NARDA \\ Department of Zoology, Panjab University, Chandigarh (India)
}

Received 7.i.64

Payne (1918), Rendel (1959) and Fraser (1963) observed that the number of scutellar bristles in Drosophila is controlled by a polygenic system. Rendel (1959) and Fraser (1963) further consider that development is canalised at four bristles so that the infrequent wildtype flies with more or less than four bristles are caused by segregation of the scutellar genes producing combinations with a summed action of more or less than four bristles. Fraser (1963) described such variation as due to "genetic leakage" of the canalised genotype. During the analysis of the genetic variability in the natural population of $D$. melanogaster from Kulu Valley such a leakage has been found in the progenies of thirteen females out of a small sample of thirty-nine females inseminated in nature.

Selection for higher number of scutellar bristles yielded some very interesting results. It was carried on for nine generations (table I) after which the individuals became sterile. During the first seven generations, ten females with the highest number of bristles and inseminated by unknown males were selected and mass cultured in each generation. In the subsequent generations the selection was extended to both the parents through pair mating. From the numbers of offspring of the pairs in the eighth and ninth generation it became evident that the sterility did not suddenly develop at the ninth generation. In the eighth generation three out of a total of nine crosses yielded comparatively low numbers of progeny and still lower fertility was shown by as many as four out of a similar set of nine crosses in the ninth generation.

A glance at table I reveals that though the selection raised the bristle number up to eight in the second generation, it failed to produce individuals 
with nine bristles until the ninth generation. This would mean that the large number of genes, which it must be assumed were accumulated from the second to the eighth generation, were insufficient to produce the ninth bristle and produce only the eighth. Such an assumption is further supported by the fact that the frequency of individuals with eight bristles increases in the successive generations of selection. It, thus, seems that there exists a "secondary canalisation zone" of bristle development at eight where a wide range of summed genetic values all lead to the expression

\section{TABLE I}

Frequency distribution of the number of scutellar bristles, average number of bristles per individual and percentage of the flies carrying the extra bristles, through nine generations of selection

\begin{tabular}{|c|c|c|c|c|c|c|c|c|c|c|c|c|c|c|c|}
\hline \multirow{3}{*}{$\begin{array}{c}\text { Genera- } \\
\text { tion }\end{array}$} & \multicolumn{12}{|c|}{ Frequency of individuals with bristles } & \multirow{3}{*}{ Total } & \multirow{3}{*}{$\begin{array}{c}\text { Average } \\
\text { no. of } \\
\text { bristles } \\
\text { per fly }\end{array}$} & \multirow{3}{*}{$\begin{array}{c}\text { Per cent. } \\
\text { of flies } \\
\text { showing } \\
\text { effect }\end{array}$} \\
\hline & \multicolumn{2}{|c|}{4} & \multicolumn{2}{|c|}{5} & \multicolumn{2}{|c|}{6} & \multicolumn{2}{|c|}{7} & \multicolumn{2}{|c|}{8} & \multicolumn{2}{|c|}{9} & & & \\
\hline & F & M & $\mathbf{F}$ & $\mathbf{M}$ & $\mathrm{F}$ & M & $\mathbf{F}$ & M & F & M & $\mathrm{F}$ & $\mathbf{M}$ & & & \\
\hline ist & $2 I$ & I I & 10 & 5 & 2 & 5 & I & $\ldots$ & ... & $\ldots$ & $\ldots$ & $\ldots$ & 55 & $4 \cdot 582$ & $41 \cdot 818$ \\
\hline 2nd & 56 & II 8 & 77 & $4 \mathrm{I}$ & 64 & 12 & I 7 & $\mathbf{I}$ & 3 & ... & $\ldots$ & ... & $3^{89}$ & 4.868 & $55 \cdot 269$ \\
\hline 3 rd & 23 & 45 & 26 & I5 & $3^{1}$ & I5 & 5 & $\mathbf{I}$ & ... & ... & $\ldots$ & $\ldots$ & 161 & $4 \cdot 93^{8}$ & $57 \cdot 766$ \\
\hline $4^{\text {th }}$ & 67 & 182 & I 28 & 105 & I 59 & 41 & 39 & 6 & 4 & $\ldots$ & $\ldots$ & $\ldots$ & 731 & 5.072 & $65 \cdot 938$ \\
\hline $5^{\text {th }}$ & 39 & 62 & $4^{8}$ & 42 & 44 & 21 & 17 & 2 & 9 & $\ldots$ & $\ldots$ & $\ldots$ & 284 & $5 \cdot 102$ & $64 \cdot 43^{6}$ \\
\hline 6 th & 66 & 88 & 75 & 40 & 64 & 37 & 36 & 7 & 14 & $\ldots$ & $\ldots$ & $\ldots$ & 427 & $5 \cdot 105$ & 63.937 \\
\hline $7^{\text {th }}$ & I 6 & 105 & 55 & I 34 & 123 & 68 & 62 & I 4 & 22 & I & $\ldots$ & $\ldots$ & 600 & $5 \cdot 485$ & $79 \cdot 833$ \\
\hline 8th & I 6 & 65 & 54 & I 23 & I 35 & I 21 & $14 \mathrm{I}$ & 35 & 39 & 3 & $\ldots$ & $\ldots$ & 732 & $5 \cdot 892$ & $88 \cdot 934$ \\
\hline $9^{\text {th }}$ & 33 & I I 4 & 78 & 105 & 97 & $3^{6}$ & 53 & & 4 & I & I & $\ldots$ & 530 & $5 \cdot 466$ & $72 \cdot 264$ \\
\hline
\end{tabular}

$$
\mathrm{F}=\text { females } \quad \mathrm{M}=\text { males }
$$

of eight bristles. In terms of polygenes, it may be concluded that although a number of genes are needed to pass the canalisation of the scutellar bristles at four, a still higher number are required to give a threshold effect to produce more than eight bristles.

The authors are indebted to Professor G. P. Sharma, Head of the Zoology Department, Panjab University, for providing the laboratory facilities and for encouragement. Thanks are also due to Professor K. Mather for making some valuable suggestions.

\section{REFERENCES}

FRASER, A. 1963. Variation of scutellar bristles in Drosophila. I. Genetic leakage. Genetics, 48, 497-514.

PAYNE, F. 1918. An experiment to test the nature of the variations on which selection acts. Indiana Univ. Stud., 5, I-45.

RENDEL, J. M. 1959. Canalisation of the scute phenotype of Drosophila. Evolution, $13,425-429$. 